\title{
TRANSLATING EVENTS, GLOSSING EXPERIENCE: EUROPEAN TEXTS AND AMERICAN ENCOUNTERS
}

\author{
E. Michael Gerli \\ University of Virginia \\ mg2u@cms.mail.virginia.edu
}

"Efficere tibi illas familiares"

Petrarch, Secretum

\begin{abstract}
References to the romancero and other literary texts stemming from the medieval tradition in early Spanish American historical documents have been interpreted in two principal ways: one linguistic, the other socio-juridical. On the one hand, they are seen as evidence that the romancero was firmly rooted in popular language and culture, specifically in the colloquial usage of the sixteenth century. On the other hand, that allusions to ballads and other belletristic references in these works, which belong primarily to the textual universe of the relaciones de méritos y servicios (often composed as self-serving justifications for questionable actions), function as a means of self-engrandizement. In this way authors conformed to discursive requirements that compelled them to portray themselves as valiant, when not heroic, subjects of the Crown. The current article proposes a third alternative; namely, that the literary references in sixteenth-century chronicles operate at another deeper epistemological level, and constitute hermeneutical strategies rooted in medieval reading and writing practices. Specifically, that they operate as glosses which process and organize knowledge in a way that allows for the assimilation of new knowledge - especially knowledge of the unknown - into the broader cultural context of the author and the reader. In them, we are able to discover at the level of language and rhetoric one of the basic gestures of colonialism: the urge to appropriate, inhabit the territory of, and dominate the Other through the Other's transformation into familiar images of the self.
\end{abstract}




\section{Keywords}

Rhetorical Construction of Early European Images of America; Historia verdadera de la conquista de la Nueva España; Bernal Díaz del Castillo; Gloss; Composition; Literary References in Early Spanish American Chronicles.

\section{Resumen}

Las referencias al romancero y otros textos literarios de raíces medievales en los tempranos documentos históricos hispanoamericanos se han interpretado de dos principales maneras: una lingüística y otra socio-jurídica. Por un lado, se consideran estas referencias como testimonios de que el romancero estaba firmemente arraigado en la lengua y cultura populares del siglo xvi. Por otro, se toman las citas y alusiones a los romances y otros textos, sobre todo en los documentos que pertenecen al universo textual de las relaciones de méritos y servicios, como medios de autoagrandamiento que surgían de la necesidad de presentarse los autores como valientes y heroicos sujetos de la Corona. El presente estudio propone una tercera alternativa al fenómeno. Propone que las referencias beltrísticas en las crónicas del siglo XVI funcionan en un nivel epistemológico más profundo, constituyéndose como estrategias hermenéuticas cuyos orígenes se pueden encontrar en las prácticas medievales de la lectura y composición de los textos. Se propone que las referencias literarias funcionan a modo de glosas que permiten organizar y procesar el conocimiento de lo ignoto. Facilitan la asimilación de nuevas experiencias e ideas, especialmente la asimilación de lo completamente desconocido, al acomodar lo totalmente nuevo a un universo cultural pre-establecido, él de los autores y lectores europeos. En estas referencias literarias se descubren en el plano retórico y lingüístico uno de los gestos básicos del colonialismo: el deseo de apropiar, dominar, y poblar el territorio del Otro al transformar éste en una imagen de uno mismo.

\section{Palabras clave}

Construcción retórica de las tempranas imágenes de América; Historia verdadera de la conquista de la Nueva España; Bernal Díaz del Castillo; Glosa; Composición de textos coloniales; Referencias literarias en las tempranas crónicas hispanoamericanas.

In a well-known passage of the Historia verdadera de la conquista de la Nueva España Bernal Diaz del Castillo writes that, while navigating along the coast of Mexico during Holy Week of I519, several of Cortés' men who had previously frequented those shores took pain to point out the mouth of the river Pedro de Al- 
varado had previously entered, and where Alvarado had plundered some 16,000 pesos worth of gold. He writes also about how Alvarado's expedition chanced upon what they called "la Isla de los Sacrificios," where they found grisly evidence of human sacrifice, as well as many other marvels. Shortly after, upon making the first landfall at San Juan de Ulúa, Díaz del Castillo goes on, a gentleman-soldier named Alonso Hernández de Puertocarrero, who had overheard the others' account of these events to Cortés while on board, turned to the captain and said without benefit of preamble:

"Paréceme, señor, que os han venido diciendo estos caballeros que han venido otras dos veces a esta tierra:

Cata Francia, Montesinos

Cata Paris la ciudad

Cata las aguas del Duero,

Do van a dar a la mar".

Puertocarrero finished by admonishing, "Yo digo que miréis las tierras ricas, y sabeos bien gobernar" (Díaz del Castillo, 1972, p. 6I). Puertocarrero’s lines come, of course, from the Carolingian ballad of Montesinos, which narrates a bloody tale of betrayal, abused honor, and exile. Without faltering, Cortés picked up the octosyllabic rhythm of the cautionary allusion, and responded with his own lines from an equally well-known Carolingian ballad, that of Don Gaiferos: "Denos Dios ventura en armas / Como al paladin Roldán", he said, "Que en lo demás, teniendo a vuestra merced y a otros caballeros por señores, bien me sabré entender" (Díaz del Castillo, 1972, p. 6I). The whole incident, essentially a dialogue couched in the form of references to the romancero or Castilian ballad tradition, serves to lend suspense to Diaz's own narrative, to heighten Cortés' self-assuredness, and to allude to the uncertain risks of failure, treachery, and banishment run by Cortés and his men just prior to the beginning of the Conquest. The American landscape that lies before them, the mouth of the Jamapa river, and the fabled city of Tenochtitlan beyond it, are translated - literally moved and transformed - into France, Paris, and the Duero River; into the imprecise but heroic landscape of the Carolingian ballad world. Cortés in his response, of course, prefers to shake off all warning and identify with the righteous Roland rather than the fated Montesinos, continuing on to compare his band of companions to the Twelve Peers of France. The citations of the two ballads in Bernal Díaz's text thus frame in an epic context the events that will unfold in the pages to come. The conquest of Mexico and the events of Bernal Díaz's youth will be embedded in a 
heroic plot, elevating the historical deeds of the Spaniards and Díaz's own role in them to the level of the fabled deeds depicted in the ballad tradition. ${ }^{\mathrm{I}}$

On another occasion, Bernal resorts yet again to the romancero, when he tells us that Cortés' soldiers composed a ballad (En Tacuba está Cortés) to commemorate the events of "la noche triste," and how Cortés in Tacuba, as he lamented the death of his men, was approached by the Bachelor Alonso Pérez, who sought to reassure him by saying that it could not be said of him what was said in the ballad, "Mira Nero de Tarpeya/a Roma cómo se ardía", a reference to the Emperor Nero's disengagement from the burning of Rome and the human tragedy that befell its citizens, as well as a trenchant comparison to the destruction of Rome and the ruin of Tenochtitlan, (Díaz del Castillo, 1972, p. 324),

The chronicles of the sixteenth century are fraught with the invocation of ballad and other literary texts in the relation of events that took place in a continent that was just beginning to reveal itself to the European imagination. In addition to Díaz del Castillo, ballad allusions and citations may be found in Fernández de Oviedo's Historia general de las Indias, where Oviedo relates the shipwreck of Alonso Zuazo in I524 and epigrammatically seals the events ironically with the words "Buenas las traemos, señor, pues que venimos acá", a line taken from the Romance del Rey Ramiro. Likewise, Cieza de León, relating Gonzalo Pizarro's plot against Almagro en 1537, glosses the intrigue with "Tiempo es, el caballero, tiempo es de andar de aquí", whose subsequent lines are left conspicuously, if elliptically, absent: "que ni puedo andar en pie,/ni al emperador servir" —a reference to losing both his horse and his knightly status--, while Diego Fernández de Palencia contemptuously glosses the flight of the royalist army at the hands of the rebellious Hernández Girón at Chuquinga, Perú, in May,I554, with a mocking ballad citation "no van a pie los romeros, que en buenos caballos van" (cited in González Pérez, 2000, pp. 23-24). In each of these instances we see the application of the verses and plots of the romancero to the new social, historical, and ideological contexts offered by the American landscape in an effort to make the latter familiar and produce a deeper understanding of the meaning of the events that are related.

In this way, the romancero, or the Hispanic ballad tradition, is very much a presence in the texts of voyages, conquest, and discovery, which leads us to ask the question, Why is this so? and more importantly, What does it mean? On all the occasions I have just described adventurers in uncertain circumstances turn

${ }^{1}$ For a detailed review of the relevant earlier scholarship on Díaz del Castillo's Historia verdadera, see Beckjord (2007, pp. I28 ff.). 
to ballads or other imaginative texts to help them not only relate but reference, flesh out, perceive, frame, and make familiar the events at the center of narratives that purport to recreate experience. The textual references serve, in effect, as a gloss to a lived experience, framing it within a known cultural and epistemological context, assimilating the event to the discourses of the European imagination. These are not mere literary evocations, but rather textual recollections that provide a grid of references (a Foucauldian dispositif) which facilitates the translation, repositioning, or recodification and understanding of something unknown in terms of something known and familiar. Via the borrowed literary references, experience undergoes a semantic transformation in the pursuit of relating the sense of an entirely new reality that seems to elude easy integration. Through these references, new peoples, landscapes, and geographies are rendered into a European code and are moved into familiar territory, making known strange events through analogy and a process of re-cognition, or a mental reprocessing by which new knowledge can be used and understood.

Literary and textual theory over the last thirty years has permitted us to see the cultural and intellectual problematic implicit in historical writing and in testimonial texts like the ones just reviewed. The work of individuals like $\mathrm{H}$. White and L. Gossman, for example, has led to the realization that the historical text fails to carry a singular meaning, and that even texts that are the product of direct experience are first rendered, filtered, and structured by the imagination; by processes beyond the face value of their words, and by forces beyond the workings of the conscious mind of the writer. Put simply, the historical text teems with hidden subtexts and motivations, and reveals a complex intellectual economy in its attempt to re-present experience. In an essay titled "The Historical Text as Literary Artifact," White notes that the writer of history "makes sense of a set of events which appear strange, enigmatic, or mysterious in its immediate manifestations by encoding the set in terms of culturally provided categories, such as metaphysical concepts, religious beliefs, or story forms. The effect of such encodations is to familiarize the unfamiliar" (White, 1978, p. 86). White goes on to say that:

"How a given historical situation is to be configured depends on the historian's subtlety in matching up a specific plot structure with a set of historical events that he wishes to endow with a meaning of a particular kind. This is essentially a literary, that is to say fiction-making operation [...] the encodation of events in terms of such plot structures is one of the ways that a culture has of making sense of both personal and public pasts" (White, 1978, p. 84). 
The references to the romancero and other literary texts in early American historical documents have been interpreted in two principal ways. On the one hand, they are seen largely as evidence that that the romancero was:

"arraigado en la expresión coloquial de los hombres del siglo xvi ya que en ese momento la cultura tradicional está plenamente vigente y posee una dinámica que le permite acompañar al hombre en todas sus actividades, no sólo en el momento de la reunión o la fiesta o el trabajo, y ello es válido aún en el nuevo ámbito apenas conocido de esa tierra sorprendente y maravillosa que es América" (González Pérez, 2000, 23-24);

and on the other hand, that it and other belletristic references that one finds in these works, which belong primarily to the textual universe of the relaciones de méritos y servicios, serve to self-engrandize and interpellate the author, who composes the text in a quest for civic recognition, and thus must conform to a demanding discursive "process by which 'The State' compels individuals to identify with the images of perfect subjects of His Majesty" (Folger, 2009, p. I5). ${ }^{2}$ Reports and letters to the Crown about a person's performance in the New World aimed at documenting achievements, often composed as self-serving justifications for questionable actions, led to a proliferation of rhetorically adorned relaciones circumscribed by, and embellished with, heroic literary texts and subtexts.

The use of the ballad tradition in Bernal Díaz, with its stories of courageous deeds, treacherous acts, bloody encounters, and unimagined adventure reflects both the linguistic and social rationales just mentioned, as well as something more. In addition, it provides the pre-text, or the framing plot structure for many of the life encounters recollected by Bernal Díaz, Zuazo, Cieza de León, and many others who tell of the American experience. Its presence in their writings reveals the intricate mechanics of similitude that governs the construction of meaning and the hermeneutics of their texts, which search for sense in personal occurrences and events by constantly bringing forth resemblances. Writing in The Order of Things about the forces which shape the matrix of the pre-Cartesian mind, Michel Foucault notes that analogy is central to the process for making sense of the world:

"it makes possible the marvelous confrontation of resemblances across space, but it also speaks of adjacencies, of bonds and joints. Its power is immense, for the similitudes of

2 See also Pastor (1992). 
which it treats are not the visible, substantial ones between things themselves; they need only be the more subtle resemblances of relations" (Foucault, 1973, p. 2I).

Bernal Díaz clothes his Historia verdadera de la conquista de la Nueva España in what is thus recognizable attire: the texts of heroic romances and other identifiable forms of European vernacular fiction. Now how and why does he do this? Quite simply, by enveloping novel, unfamiliar experiences in recognizable narratives. Since the appearance of William H. Prescott's History of the Conquest of Mexico in 1845 , the latent importance of literary texts and literary discourse to Bernal Díaz's history has been acknowledged. The blind Prescott paraphrasing Díaz del Castillo in I843 had clearly seen the significance of the literary and cultural residues that shaped the Historia verdadera:

"All round the margin, and occasionally far in the lake, they beheld little towns and villages, which, half concealed by the foliage, and gathered in white clusters around the shore, looked in the distance like companies of white swans riding quietly on the waves. A scene so new and wonderful filled their rude hearts with amazement. It seemed like enchantment; and they could find nothing to compare it with, but the magical pictures in the Amadis de Gaula. Few pictures, indeed, in that or any other legend of chivalry, could surpass the realities of their own experience. The life of the adventurer in the New World was romance put into action. What wonder, then, if the Spaniard of that day, feeding his imagination with dreams of enchantment at home, and with its realities abroad, should have displayed a Quixotic enthusiasm,-a romantic exaltation of character, not to be comprehended by the colder spirits of other lands." (Prescott, I98I, III: 8: pp. 29I-92).

Díaz's comparison, and Prescott's seizure of it, should not surprise us: the chroniclers lived experiences so unique that comparable scenes could only be found in the storehouse of imaginative literature, the world of the familiar fantastic - that is, in the collective literary imagination of medieval European civilization. On every page in the literature of discovery experience is mediated not just by spoken language, memory, and the imagination but by a vivid recollection of an established textual tradition. We see that tradition of texts constantly at work, falling back upon itself in the quest to order and stabilize the volatile images offered up by the world of lived experience. Only writing and references to written texts provided a medium that allowed the relation of such novel events (the pun is intended).

Literary references and actual occurrences converge as a result of the desire to interpret what has occurred, forging narratives that, it could be argued, are the precursors of that prodigious blend of reality and fantasy critics of Latin Ameri- 
can fiction have termed magic-realism, in which certain truths seem stranger than fiction and can only be believed by displacing them toward the realm of known fantasy. The methods and strategies of fiction provide, paradoxically, the means for relating the vivid novelty of the New World in Bernal Díaz's Historia verdadera. Diaz's discursive invocation of the truth paradoxically relies on his readings of medieval imaginative literature. In his book, we see America through a rhetoric of Spanish fiction since only the texts of fiction and fantasy could suffice to depict, highlight, dramatize, and claim his story for European history.

On one occasion, for example, Díaz del Castillo recreates a dialog between doña Marina with an old Indian woman, in a text that impresses the literate reader as redolent with echoes of Celestina. It is dark, the air is filled with an odor of suspicion and conspiracy; the old woman, who had hoped to arrange an advantageous marriage for her son with la Malinche, takes Doña Marina aside, urges her to flee, and whispers that there is a conspiracy afoot among the papas to kill everyone in the Spanish camp at Cholula. As subtle and perspicacious as Celestina herself, doña Marina thanks the old woman and artfully wins her confidence, as she probes and cajoles to uncover the details of the Aztec plot kill Cortés and his men:

“ $\mathrm{Oh}$, madre, qué mucho tengo que agradeceros! Eso que decís, yo me fuera con vos, pero no tengo aquí de quiém me fiar mis mantas y joyas de oro, ques muchos; por vuestra vida, madre, que aguardéis un poco vos y vuestro hijo, y esta noche nos iremos que ahora ya véis que estos teules están velando, y sentirnos han" (Díaz del Castillo, 1972, pp. I46-I47).

Having won time through persuasive deception, Doña Marina promptly informs Cortés of the plot. It is clear, of course, that neither the old Aztec woman nor Doña Marina ever spoke in the way Díaz describes their encounter. It is abundantly clear, also, that Doña Marina's dissimulation and the old crone's stratagem to sow doubt among the Spaniards through the transparent excuse of marrying her son to la Malinche resonate with irony and the discursive subterfuges of the dialogs in Celestina. Díaz del Castillo artfully weaves in intertextual echoes from Celestina at this juncture not only to lend verisimilitude to his work, but to cast the crucial meeting between these two native women in a linguistic universe that was fraught with conspiratorial overtones and was already more than familiar to his readers. ${ }^{3}$

3 The reader's privileged ironical perspective, Doña Marina's false gratitude, and her bogus rhetorical endearment (“ $¡ \mathrm{Oh}$, madre, qué mucho tengo que agradeceros!”), highlight the air of mutual betrayal that frames the scene and would doubtless have immediately resonated with echoes of 
Similarly, in what is perhaps the most vivid portrait of Moctezuma to be found in the literature of the Conquest of Mexico, we see Díaz's quest for a means to describe the Aztec King come to rest upon the paradigm of the biographical portrait, or descriptio, as it was defined in medieval Castilian historiography first by López de Ayala in his chronicles, but above all later by his nephew, Fernán Pérez de Guzmán in his Generaciones y semblanzas, which was available to Bernal Díaz in printed form since the I5I2 Valladolid edition:

"Era el gran Montezuma de edad de hasta cuarenta años y de Buena estatura e bien proporcionado e cenceńo, e pocas carnes, y la color ni muy Moreno, sino propio color e matiz de indio, y traía los cabellos no muy largos, sino cuanto le cubrían las orejas, e pocas barbas prietas e bien puestas e ralas, y el rostro algo largo y alegre, e los ojos de buena manera, e mostraba en su persona en el mirar, por un cabo amor e cuando era menester gravedad; era muy polido e limpio, banábase cada día una vez a la tarde" (Díaz del Castillo, p. I66). ${ }^{4}$

The texts, subtexts, and explicit references we have examined are, in effect, two things: on the surface, they are the spontaneous recollections and associations of authors and chroniclers; and at a deeper level, they constitute an interpretive paradigm and a hermeneutical strategy that is firmly rooted in a textual tradition, an established epistemology, or a way of processing and organizing knowledge - especially knowledge of the unknown - that permits the justification and assimilation of new images into the broader cultural context of the enunciative voice of the text and the reader. Beyond the relation of events, one of the roles of these texts is to mold attitudes and beliefs that draw members of a society together in solidarity. The references to known plots and motifs thus may be seen as sites of collaboration between the writer and his intended readers where statements of common interests and aspirations are displayed and become instruments in the establishment and articulation of a group dynamic vital to the construction of the earliest European images of America. They are parenthetical references that break the basic syntax of the narrative - the nature and sequence of the events described - to call attention to certain common points of reference

Celestina to Díaz's readers in 1575 , when the manuscript of the Historia verdadera first began to circulate in Spain. On the Celestinesque references in the Historia verdadera, see Johnson (1981, 1997) and Montaudon (2007).

4 The portrait of Montezuma drawn by Díaz should be compared, for example, to the one of King Juan II penned by Pérez de Guzmán (Pérez de Guzmán, 1965, p. II7-I8). The rhetorical similarity is striking. 
that remind both reader and writer that, although what is represented is meant to be seen as astonishingly new, it is not so new as to not be somehow déjà vu. If Díaz draws upon the romancero, the romances of chivalry, and other modes of European imaginative literature, he does so to move the events he describes closer to his own and his reader's cultural realm, to make the European mind grasp their uncanniness by reference to an already familiar universe of discourse. It is a strategy, as Freud might say, to make the Unheimlich Heimlich.

To give examples or comparisons is always an attempt to offer a commentary that seeks to extract a larger meaning. As such the comparisons and examples that Díaz del Castillo draws upon become constitutive elements of his narrative that serve as strategies to organize, domesticate, and explain the events that he relates, as well as to open up a common space for dialog with his public. They are invitations to the larger interpretive possibilities of his text, and they beckon the reader to add to its surplus, as Marie de France's famous formulation of interpretive reading put it. 5 They bring the events that are told closer to the reader's understanding, pointing out things that were known by the reader before picking up Díaz's history, thus charging his text with hermeneutical possibilities. Their understanding depends not so much on the events of the text itself, than on the ready recognition of it by readers as something that belongs to their cultural universe. At the same time, of course, the American experience Díaz relates forfeits the full possibility of being unique as it moves toward the chivalric world; it renounces the claim that it might be something entirely new and independent as it is transformed into an amplification of Europe. The narrative, in this way, is understood as an extension of the chivalric world, even though the point of comparison belongs entirely to the realm of imaginative literature. Thus fiction offered the power to convey, make known, and transform something that was nameless into something that could be named.

In yet another description fraught with comparisons, we see how the town of Mezquiqui for Díaz and his companions becomes Venezuela, a small representation of Venice on the lake, and how ultimately, as they neared Tenochtitlan, the shining towers of the metropolis and the landscape itself could only be captured through the lens of Amadis:

5 "Custume fu as anciens, / Ceo testimoine Preciens, / Es livres ke jadis feseient,/ Assez oscurement diseient/ Pur ceus ki a venir esteient/ E ki aprendre les deveient,/ K’i peüssent gloser la letter/ E de lur sen le surplus mettre" (Marie de France, 1978, lines 9-17). 
"Y acabada la plática, luego nos partimos, e como habían venido aquellos caciques que dicho tengo, traían mucha gente consigo y de otros muchos pueblos que están en aquella comarca, que salían a vernos. Todos los caminos estaban llenos dellas que no podíamos andar, y los mismos caciques decían a sus vasallos que hiciesen lugar, e que mirasen que éramos teules, que si no hacían lugar nos enojaríamos con ellos. Y por estas palabras que les decían nos desembarazaron el camino e fuimos a dormir a otro pueblo que está poblado en la laguna, que me parece que se dice Mezquiqui, que después se puso nombre Venezuela, y tenía tantas torres y grandes cues que blanqueaban, y el cacique dél e principales nos hicieron mucha honra, y dieron a Cortés un presente de oro e mantas ricas, que valdría el oro cuatrocientos pesos; y nuestro Cortés les dió muchas gracias por ello [...] Y otro día por la mańana llegamos a la calzada ancha y vamos camino de Estapalapa. Y desque vimos tantas ciudades y villas pobladas en el agua, y en tierra firme otras grandes poblazones, y aquella calzada tan derecha y por nivel cómo iba a Méjico, nos quedamos admirados, y decíamos que parescia a las cosas de encantamiento que cuentan en el libro de Amadís, por las grandes torres y cúes y edificios que tenían dentro en el agua, y todos de calicanto, y aún algunos de nuestros soldados decían que si aquello que vían, si era entre sueños, y no es de maravillar que yo lo escriba aquí desta manera, porque hay mucho que ponderar en ello que no sé cómo lo cuente: ver cosas nunca oídas, ni vistas, ni aun soñadas, como víamos" (Díaz del Castillo, 1972, p. I59).

There is more here than simple literary reference, however. Marvel is produced on both sides as subjects and objects trade places at various moments in Díaz's discourse. The city is not the only prodigious text Díaz notes. He is aware that he, Cortés, and the other Spaniards were also the objects of observation, referred to as "teules" and magicians, matters of equal wonder and admiration to Aztec eyes. The observer feels himself observed and circumscribed by astonishment, as if he had become a character in the novel of chivalry that provides the comparison and the seat of memory for his rhetorical invention. While the reference to Amadis constitutes an attempt to move the reader towards the native culture it is also a gesture of allegiance. Through it, the shadow of the chivalric is cast upon the landscape and the text's protagonist narrator is implicitly identified with the paladins of fiction. The reference that comes to mind when compelled to ponder and relate these things "nunca vistas, ni oídas, ni aun soñadas, como víamos" points directly to the universe of heroic achievement portrayed in chivalric fiction. In order to ponder and portray a place like Tenochtitlan it must be not so much depicted as altered and transported into a European universe of known texts where the Other is subaltern.

We should not be surprised that Díaz narrated the new in terms of the old. It is the only adequate strategy to employ when seeking a propitious medium 
with which to persuade and convey the uncanny. It is paradoxical, of course, that the pursuit of factual recollection should be embellished and so circumscribed by comparisons to remembered plots and texts of imaginative literature. The pursuit of history embraces fiction here since, as Díaz declares, the medium for transforming into words what he and his companions lived and saw simply did not exist ("hay mucho que ponderar en ello que no sé cómo lo cuente"). Only fiction can suffice as referent.

Writing of the initial European inability to respond to America, J. H. Elliott notes that there is really nothing new in this attitude:

"Medieval Europe had found it supremely difficult to comprehend and come to terms with the phenomenon of Islam [...] Nor is this a matter for surprise for the attempt of one society to comprehend another inevitably forces it to reappraise itself [...] This process is bound to be an agonizing one, involving the jettisoning of many traditional preconceptions and inherited ideas. It is hardly surprising, then, if sixteenth-century Europeans either ignored the challenge or baulked at the attempt. There was, after all, an easier way out, neatly epitomized in 1528 by the Spanish humanist, Hernán Pérez de Oliva, when he wrote that Columbus set out on his second voyage 'to unite the world and give those strange lands the form of our own." (Elliott, 1970, pp. I4-I5). ${ }^{6}$

It is for this reason that the images in Díaz's description of Tenochtitlan cannot stand alone, they must be mediated through Amadis for their full conveyance and assimilation. To be more fully comprehended, Tenochtitlan had to be organized in terms of a well-known, if fictive, text. The actual point of memory and comparison from Book I, Chapter XI of Amadis de Gaula follows:

"Y al tercero día [...] partieron de allí y fueron su camino, y al quinto día halláronse cerca de un Castillo muy fuerte que estava sobre un agua salada. Y el castillo havía nombre Bradoyd, y era el más hermoso que havía en toda aquella tierra, y era assentado en una alta peńa, y de la una parte corría aquella agua y de la otra havía un gran tremedal; y de la parte del agua no podían entrar sino por barca y, de contra el tremedal havía una calçada tan ancha que podia yr una carreta y otra venir, mas a la entrada del tremedal havía una puente estrecha, y era echadiza y quando la alçaban quedava el agua muy fonda, y a la entrada de la puente estavan dos olmos altos. Y el gigante y Galaor vieron debaxo dellos

${ }^{6}$ Pérez de Oliva’s observation in the original Castilian reads that Columbus "partió de España año siguiente de la primera navegación, a mezclar el mundo y a dar a aquellas tierras estrañas forma de la nuestra" (Pérez de Oliva, 1965, pp. 53-54). For further elaboration on the first European contact with, and interpretation of, the new American reality see Grazinski (2004) and Elliott (2006). 
dos donzellas y un escudero, y vieron un cavallero armado sobre un cavallo blanco" (Rodríguez de Montalvo, 1997, I, p. 90).

Díaz's recollection, his rhetorical craft as a writer, and the shared cultural experience of a common set of texts with the reader all coalesce in the Historia verdadera through the references to works like Amadis and the Carolingian romancero. However, the story that emerges embroidered in this manner serves not just to commemorate events but to explain and justify the outcome of the Spanish conquest and his role in it. Díaz's rhetorical invention constantly appeals to the heroic loci of memory and points to an abiding concern for the construction of a viable and acceptable public history for him and his companions, a myth generated entirely from within the European epistemological system to encompass the nature of the Spanish conquest and the subsequent domination of what was tellingly called Nueva Espana. The textual construction of that "reality" consists of a web of references, images, and symbols that are deeply embedded in the European imaginary. If the Spaniards triumph over the Aztecs, it is simply because they belong to the world and the culture from which their textual allusions and comparisons spring, righteous, puissant, resilient, ultimately invincible, and heroic. During the first half of the sixteenth century Amadis de Gaula and the Carolingian romancero were not, as they are today, bibliographical curiosities, archaeological repositories of chivalric values, lore, and improbable adventure. They were intensely contemporary texts, actively read, commented upon, celebrated by an enthusiastic readership, and received as exhortations to heroic conduct. Their invocation in Díaz's history establishes a fluid process of reference, readerly movements toward these texts that succeed in making imaginative connections between widely separated people, places, and times.

I have dwelt on Bernal Díaz precisely because I think that he is perhaps the most representative example of the way the early chroniclers sought to reference and translate the novelty of the American experience in European terms. Díaz epitomizes the economies of thought used by Europeans to confront New World realities. The direct allusions to, and the subtle rhetorical subterfuges of, Amadis, Celestina, the romancero, and Generaciones y semblanzas I have underscored, in addition to the myriad other comparisons Díaz draws between Aztec Mexico and Europe, are more than observed similarities; they are gestures for approximating the known to the unknown as well as for exercising dominion over the latter. The references function as glosses to recalled experience. They are constituted parenthetically, almost like the interlinear glosses and translations of texts with cross references to similar passages one finds in medieval manuscripts. In this way, they 
seek not just to explicate but to create a standard of reference, like the so-called sedes materiae (literally: seat of the matter) in medieval commentaries of civil and canon law, or in a broader cultural setting, they function like Levi-Strauss' bonnes à penser, or things with which to think (Levi-Strauss, 1962, p. 32). In its proper form glossing can clarify what is obscure in texts and strip away the external covering in which writers clothe the truth in their texts.

The elaboration of glosses constituted an important component of composition and exegesis, and they functioned much like reference tools, seeking to tease out the meanings and uses not just that the author but that his readers could find in any particular text. At the same time, as C. Dinshaw asserts, "Glossing is a gesture of appropriation; the glossa undertakes to speak the text, to assert authority over it, to provide an interpretation, finally to limit or close it to the possibility of heterodox or unlimited significance." The gloss "reveals and makes useful the text's hidden truth, recloaking the text with its own interpretation," and it opens the possibility of "the delight of understanding [the text's] spirit" just as it can "overwhelm the text as well" (Dinshaw, 1989, p. I22) To be sure, as Rodríguez Velasco (2010) has shown, the practice of glossing in late fifteenthcentury Spain still remained widespread, and the gloss could often eclipse the very authority of the text that was its object in the manner described by Dinshaw. Glossing encouraged the reader to draw upon known elements which carry symbolism and meaning, and to combine them to form a complex hermeneutical network of associations in an exercise of interpretation. Their more profound objective was not only to group concepts and events together but also to suggest and constitute meaningful abstract relationships between them. In the texts we have examined, they constitute the European attempt to register, assimilate, and domesticate the powerful nature of otherness: the range of geographies, experiences, cultures, representations, and individuals with whom people like Díaz were suddenly forced to interrelate. In them, we are able to discover at the level of language, text, thought, and sensibility one of the basic gestures of colonialism: the urge to appropriate, inhabit the territory of, and dominate the Other through the Other's transformation into familiar images of the self. The texts we have examined all seek to bridge the gap of New World Otherness. The density of analogies and comparisons that one finds in early Spanish descriptions of, and narratives on, America does not, however, signal successful understanding of the historical subjects that were the objects of their interest. On the contrary, the cultural realities and understandings of the Spaniards and the Americans made any form of mutual comprehension almost impossible. In the texts we have reviewed, the relation and comprehension of an unknown world implies its association and 
inscription in preexisting representations defined by a dominant European subjectivity and textual tradition. The point is simply that, even if failed, the effort to understand was for lack of a two-way dynamic, and for the fact that in their initial experiences in the New World, the Spanish could only absorb America by colonizing it physically, socially, and textually; by transforming it into Europe, even at the level of rhetoric and writing. To paraphrase and slightly bend Todorov's well-known declaration of purpose at the beginning of his The Conquest of America, through these textual references to European narratives, the self found the self in its vision of the other (Todorov, 1984, p. 3).

WORKS CITED

Beckjord, S. H., 2007: Territories of History: Humanism, Rhetoric, and the Historical Imagination, in the Early Chronicles of Spanish America, University Park, PA.

Carmona Fernández, F., 1993: "Conquistadores, utopía, y libros de caballería," Revista de Filología Románica, IO, pp. II-29.

Chicote, G. B., I998: "El romance en las Crónicas de Indias: nuevos mundos narrados con viejos textos," Actas del IV Congreso Internacional AISO, Alcalá de Henares, pp. 50I-508.

—, 2003: "La lexicalización de la experiencia: el romancero en la prosa historiográfica de Bernal Díaz del Castillo,” Romance Quarterly, 50, pp. 269-279.

—, 20I2: "La literatura valida la acción: los géneros ficcionales en la prosa historiográfica de Bernal Díaz del Castillo," Anales de Literatura Hispanoamericana, 4I, pp. 6I-79.

Dinshaw, C., 1989: Chaucer's Sexual Poetics, Madison.

Díaz del Castillo, B., $1972^{9}$ : Historia verdadera de la conquista de la Nueva España (ed. de J. Ramírez Cabañas), México.

Elliott, J. H., 1970: The Old World and the New, I492-1650, Cambridge.

-, 2006: Empires of the Atlantic World: Britain and Spain in America I492-I830, New Haven.

Estrada, O., 2009: La imaginación novelesca: Bernal Díaz entre géneros y épocas, Madrid - Frankfurt am Main.

Folger, R., 2009: Picaresque and Bureaucracy: "Lazarillo de Tormes", Newark (Delaware).

Foucault, M., 1973: The Order of Things: An Archaeology of the Human Sciences, New York. 
García Castillo, J. E., 20I2: Excurso y discurso de Bernal Díaz del Castillo, México.

Gilman, S., 196r: "Bernal Díaz del Castillo and Amadis de Gaula," Studia Philologica. Homenaje ofrecido a Dámaso Alonso por sus amigos y discípulos con ocasión de su 60 aniversario, 3 vols, Madrid, vol. 2, pp. 99-II3.

González Pérez, A., 2000: "El romancero en América y la tradición cubana", América sin nombre, 2, pp. 22-34.

Gossman, L., 1990: Between History and Literature, Cambridge (Massachusetts).

Grazinski, S., 2004: Les quatre parties du monde. Histoire d'une mondialisation, Paris.

Hernández y Sánchez Barba, M., I960: "La influencia de los libros de caballerías sobre el conquistador," Revista de Estudios Americanos, 19, pp. 215-236.

Johnson, J. G., 1981: "The Celestinesque Figures of Colonial Spanish American Literature," Celestinesca, 5, pp. 42-46.

—, I997: "Bernal Díaz and the Women of the Conquest," Writers of the Spanish Colonial Period (ed. D. W. and D. Altamiranada), New York, pp. I59-I69.

Levis-Strauss, Cl., 1962: The Savage Mind /La Pensée sauvage (trans. E. Leach), Chicago.

Marie de France, 1978: Les lais de Marie de France (ed. J. Rychner), Paris.

Marrero-Fente, R., 20I0: "Aztec Ghosts and the Voice of Death in Romances and Songs Related to the Conquest of Mexico," Bodies, Texts, and Ghosts: Writing on Literature and Law in Colonial Latin America, Lanham, MD, pp. 6I-65.

Menéndez Pidal, R., 194I: Los romances de América, Buenos Aires, pp. 9-IO.

Montaudon, Y., 2007: "Las Fuentes literarias de la construcción bernaldiana de Doña Marina," Signos Literarios, 5, pp. 39-70.

Pastor, B., 1992: The Armature of Conquest: Spanish Accounts of the Discovery of America, I492-1589 (trans. L. Longstreth Hunt), Palo Alto (California).

Pérez de Guzmán, F., 1965: Generaciones y semblanzas (ed J. Domínguez Bordona), Madrid.

Pérez de Oliva, F., 1965: Historia de la Invención de las Yndias (ed. J. J. Arrom), Bogotá.

Prescott, W. H., 1981: History of the Conquest of Mexico and History of the Conquest Of Peru, New York.

Reynolds, W., I967: Romancero de Hernán Cortés, Madrid, pp. 25-26.

Rodríguez de Montalvo, G., I997: Amadís de Gaula (ed. J. Rodríguez Velasco), 2 vols., Madrid.

Rodríguez Prampolini, L., 1949: Los Amadises de América: La hazaña de Indias como empresa caballeresca, México. 
Rodríguez Velasco, J., 2010: "La producción del margen”, La Corónica, 39/I, pp. 249-72.

Romero, A. F., 1988: "La falacia antirretórica de Bernal Díaz del Castillo," Revista de Crítica Literaria Latinoamericana, pp. 337-344.

Sáenz de Santamaría, C., 1967: Introducción crítica a la Historia Verdadera de Bernal Díaz del Castillo, Madrid, pp. II9-I2I.

Sánchez, A., 1958: "Los libros de caballerías en la conquista de América," Anales Cervantinos 7, pp. 237-259.

Thomas, H., 2012: "Amadís en América", Revista de la Universidad de México, 95, pp. 5-9.

Todorov, T., 1984: The Conquest of America: The Question of the Other (trans. R. Howard), New York.

White, H., 1978: Tropics of Discourse, Baltimore. 